\title{
Other primary headaches-thunderclap-, cough-, exertional-, and sexual headache
}

\author{
Anish Bahra ${ }^{1}$ D \\ Received: 2 September 2019 / Revised: 21 January 2020 / Accepted: 23 January 2020 / Published online: 4 March 2020 \\ (c) The Author(s) 2020
}

\begin{abstract}
This article reviews the disorders of thunderclap, cough, exertional and sexual headache. These are a group of paroxysmal and precipitated headaches, which often occur in bouts with prolonged remissions. Indometacin seems to be the most effective preventative. Each can occur in primary and secondary form. Thunderclap headache is the most frequently reported headache syndrome associated with a secondary pathology. Discussed are the complexities of whether all patients with thunderclap headache should have further investigation if timely computerised tomography is normal and, the relevance of abnormal imaging in these disorders, differentiating what is deemed to be secondary and managing the pain.
\end{abstract}

Keywords Thunderclap headache $\cdot$ Cough headache $\cdot$ Exertional $\cdot$ Sexual $\cdot$ Coital $\cdot$ Orgasmic headache

\section{Introduction}

A primary headache is synonymous with a headache disorder having no clear correlating aetiology on examination of the patient nor on structural imaging. The terminology has evolved from 'benign' and 'idiopathic' to the current use of 'primary'. The majority of individuals experience spontaneous and recurrent episodes of self-limiting pain. The International Classification of Headache Disorders (ICHD) has been successful in refining phenotypes which, based upon history alone, provides well-defined clinical syndromes [1] likely to respond to specific treatments.

Knowledge of the primary headaches comes largely from the work in the most prevalent disorders, namely tensiontype headache, migraine, and cluster headache. This supports the concept that these disorders occur in those genetically predisposed [2-4] and, where the inherent pathology is in the central nervous system. When individuals first experience a headache, the concern is often about a sinister precipitating pathology [5]. However, in patients presenting with tension-type headache, or migraine with and without typical aura and a normal neurological examination, the prevalence

Anish Bahra

a.bahra@nhs.net

1 The National Hospital for Neurology and Neurosurgery, University College London (UCL), Queen Square, Box 80, London WC1N 3BG, UK of an underlying brain lesion is the same as that in an asymptomatic population $[6,7]$. With more uncommon disorders, acquiring population-based data is much more challenging and the literature is confounded by publication bias.

Part I of the ICHD orders the primary headaches into four sections: migraine, tension-type headache, the trigeminal autonomic cephalalgias and a fourth groups of miscellaneous, largely paroxysmal headache disorders. Although the fourth section of the ICHD has been one into which miscellaneous disorders have been consigned the grouping does reflect syndromic and, pathophysiological alignment. Most of the syndromes are precipitated, paroxysmal and usually short-lived (Table 1). Moreover, the most consistent preventative treatment seems to be Indometacin. New daily persistent headache is the exception; whether this is indeed a distinct pathological entity remains to be determined.

This review will focus on primary thunderclap, cough, exertional, and sexual headache. Each disorder can occur in primary and secondary forms.

\section{Thunderclap headache}

\section{Clinical syndrome}

Thunderclap headache $(\mathrm{TCH})$ describes a sudden severe explosive onset headache. The severity itself is not 
Table 1 The other primary headaches [1]

Primary cough headache
Primary exercise headache
Primary headache associated
with sexual activity
Primary thunderclap headache
Cold stimulus headache
External-pressure headache
Primary stabbing headache
Nummular headache
Hypnic headache
New daily persistent headache

diagnostically helpful [8-10], it is the rapidity of onset, with pain developing from zero to maximum in seconds to minutes.

\section{Epidemiology}

Landtblom has provided the only population-based data citing an incidence of 43 per 100,000 persons ( $>18$ years) per year of all sudden onset headache (within $10 \mathrm{~s}$ ) [9] with primary TCH (PTCH) being cited as occurring in 38 per 100,000 persons per year.

\section{Primary and secondary thunderclap headache}

It is best to understand $\mathrm{TCH}$ from a historical perspective. Isolated thunderclap onset headache is the most consistently reported presentation of a secondary headache, with the time frame of the pathology and onset of the headache supporting an association [5]. The term 'isolated' infers the headache to be in neurologically and systemically intact patients. The most dramatic presentation is subarachnoid haemorrhage $(\mathrm{SAH})$; one third present with isolated headache. It is from this literature that our knowledge of TCH has evolved. The prevalence of spontaneous SAH is about nine cases per 100,000 people a year, thus a rare disease [11]. The disproportionate attention it has garnered lies in the high mortality. A meta-analysis of 33 studies reported a casefatality rate of $8 \cdot 3-66 \cdot 7 \%$ (variability depending on country of data acquisition). Also reported was a $17 \%$ reduction in case-fatality over three decades, an observation supported in subsequent populations [12]. The improvement has been attributed to better management, primarily rapidity of access to medical care.

Of all spontaneous SAH, $85 \%$ are aneurysmal while $10 \%$ are perimesencephalic, thus venous and carrying a generally benign prognosis. The most definitive method of diagnosis is unenhanced computerised tomography (CT), which will show SAH in $99 \%$ of cases if imaged within $6 \mathrm{~h}$ of ictus [13, 14]. In those with negative CT, examination of cerebrospinal fluid (CSF) for altered blood products remains positive from $12 \mathrm{~h}$ to 2 weeks in $100 \%$ of cases [15-17]. The risk of angiography in lieu of CSF examination, or in late presentations, is detection of an incidental aneurysm and potential unnecessary and cost- ineffective intervention [18, 19]. It has been argued that using third generation CT scans to image patients within $6 \mathrm{~h}$ of ictus, the sensitivity and specificity for detecting aneurysmal subarachnoid haemorrhage is $100 \%$. While the detection of subarachnoid blood on CT- negative patients is about $7 \%$, the cause for the CSF xanthochromia in these patients runs a benign course $[20,21]$.

The existence of a benign form of thunderclap headache is supported by longitudinal observations of patients investigated with normal CT and CSF examinations who did not develop any subsequent adverse sequalae and continued to experience recurrent attacks (Table 3). Moreover, it was shown that clinically it is not possible to reliably differentiate those who have experienced a subarachnoid haemorrhage from those with subsequently normal investigations $[8,9,22-25]$. In both groups the onset of the headache is within seconds to a few minutes in most; in $20 \%$ escalation of severity can be greater than $5 \mathrm{~min}[8,10]$. There is no difference in severity, past history of headache, precipitating event (exertion or valsalva) nor additional neurological symptoms. Moreover all groups had previously experienced similar TCH. Clinical guidelines have been developed for diagnosing SAH in patients presenting with acute headache with almost $100 \%$ sensitivity but poor specificity of $13.6 \%$ [26].

Thunderclap onset headache has also been associated with a multitude of secondary pathologies. A systematic review of the literature from 2014 identified 119 causes in a total of 2345 cases reported in isolation, case series or cohorts [27]. The diagnoses relied on the combination of 'sudden' and 'severe'. The definition of 'sudden' was not detailed and it was acknowledged that the majority had not used ICHD criteria. Within each pathological category are a number of likely incidental findings.

By far the largest contribution was primary headache in 459 cases, 213 primary thunderclap headaches, followed by primary sexual headache in 182, bath-related headache in 37 and exertional headache and combinations of the aforementioned. Three-hundred and ninety-eight cases were precipitated by cerebrovascular disorders, 206 from SAH, 46 from other sources of intracranial haemorrhage, venous and arterial thromboembolism, intracranial dissection, stroke, hypertensive encephalopathy and vasculitis. Included were 18 cases likely to be incidental findings, primarily unruptured cerebral aneurysms. One hundred and sixty cases of sudden and severe headache were reported in association with infection, $44 \%$ affecting the CNS and the remainder systemic with likely CNS involvement or, encompassed within the terminology of a 'viral illness' without further elaboration. One hundred and seventy-three patients were diagnosed with 
reversible vasoconstrictive 'syndrome' (RCVS). The largest contribution to the 119 non-vascular precipitants was from pituitary apoplexy in 43 cases and 32 related to alterations in CSF pressure. Less than 20 cases were related to the peripartum state and drugs.

The current ICHD of primary thunderclap headache defines the rapidity of onset as being within $1 \mathrm{~min}$ (Table 2). This will capture up to $75 \%$ of primary and secondary thunderclap headache, while altering this definition to escalation within 5 min will capture $95 \%$ of cases [8]. The subsequent headache, following the initial thunderclap, most frequently has clinical features consistent with migraine (Table 3).

In summary, TCH is the most common headache syndrome associated with a secondary precipitating pathology. The majority will have PTCH [9]. Primary and secondary thunderclap headache, however, cannot be reliably differentiated clinically thus, all patients should be investigated. Within $6 \mathrm{~h}$ of ictus, it is likely that aneurysmal SAH can be identified by $\mathrm{CT}$ alone. However, late presentations and less common causes, will require further investigation.

\section{Cough headache}

The lifetime prevalence of primary cough headache is reported as $1 \%$ [28]. The disorder has a male predominance.

Table 2 gives the current definition for cough headache and Table 4 the characteristics of published cohorts.

Cough headache is precipitated (rather than aggravated, as occurs in migraine) by a valsalva manoeuvre such as coughing, sneezing, bending, straining and, laughing (with genuine mirth) [29]. The pain is immediate, short-lived, usually bilateral and with a paucity of additional features. The periods of time during which individuals are symptomatic does tend to be self-limiting, lasting months or a few years at most [30-34].
Rooke's original cohort of 103 patients, observed over three years, although titled 'Exertional headache' was a combination of valsalva related headache and exertional headache [35]. Most of the precipitants were valsalva manoeuvres, except for one which was running. Of these, 30 went into remission within 5 years and 73 improved or were free from headache at 10 years. Ten had an abnormality on imaging, an Arnold-Chiari malformation (ACM) in 3, platybasia in one, basilar impression in 2, subdural haematoma in 2 (non-acute), a parietal glioma in one and cerebellar haemangioendothelioma in one. In the patient with a known subdual collection over 20 years symptoms improved spontaneously without intervention. The glioma was detected 3 years after the onset of symptoms. The majority operated on had either resolution or improvement of the disorder.

Valsalva can precipitate other headache phenotypes, for example valsalva-induced cluster headache, paroxysmal hemicrania, hemicrania continua [36-38] and as described, thunderclap headache (Table 3). Rozen reported seven patients who presented with valsalva precipitated new daily persistent headache, five of whom had characteristics of migraine.[39]. Some patients may need combination therapy with treatments effective for each headache phenotype.

\section{Treatment}

The most consistent treatment is Indometacin, effective over a dose range between 25-250 mg. Mathew first reported the response to Indomethacin in a double-blind placebo controlled manner in two patients with cough headache resistant to other tried preventatives [40]. Response was achieved in 1-4 weeks and maintained over an 18 month follow-up period.

The aim is to achieve an optimal dose which successfully suppresses the symptoms and then periodically reduce the dose to see whether the symptoms have become quiescent $[30,32,33]$.

Table 2 International classification of headache disorders [1]

Thunderclap headache

Cough headache

Exercise headache

Headache associated with sexual activity

\author{
Abrupt onset, reaching maximum intensity in $<1 \mathrm{~min}$ \\ Lasting for $\leq 5 \mathrm{~min}$ \\ Sudden onset \\ Brought on by, and occurring only in association with, coughing, straining and/or other \\ Valsalva manœuvres \\ Lasting between $1 \mathrm{~s}$ and $2 \mathrm{~h}$ \\ Brought on by, and occurring only during or after, strenuous physical exercise \\ Lasting $<48 \mathrm{~h}$ \\ Brought on by and occurring only during sexual activity \\ Either or both of the following: \\ 1. Increasing in intensity with increasing sexual excitement \\ 2. Abrupt explosive intensity just before or with orgasm \\ Lasting from one minute to $24 \mathrm{~h}$ with severe intensity and/or up to $72 \mathrm{~h}$ with mild intensity
}

The assumption of a primary disorder is recurrence ( $>1$ attack) with no evidence for an alternative secondary precipitating pathology 
Table 3 Thunderclap headache

\begin{tabular}{|c|c|c|c|c|c|c|c|c|c|}
\hline Publication & $\mathrm{N}$ & $\begin{array}{l}\text { Mean Follow- } \\
\text { up (years) }\end{array}$ & Past TCHA \% & $\begin{array}{l}\text { Recurrent } \\
\text { TCHA \% }\end{array}$ & $\begin{array}{l}\text { Subsequent } \\
\text { primary } \\
\text { HA \% }\end{array}$ & $\begin{array}{l}\text { Prior primary } \\
\text { HA\% }\end{array}$ & $\begin{array}{l}\text { Precipitant to } \\
\text { onset }\end{array}$ & Duration & $\begin{array}{l}\text { Additional } \\
\text { features (\%) }\end{array}$ \\
\hline $\begin{array}{l}\text { Wijdicks } 1988 \\
{[22]} \\
\text { PTCHA }\end{array}$ & 71 & 3.3 & 10 & 17 & 44 & - & $\begin{array}{l}\text { Cough } 7 \% \text {, } \\
\text { sex } 4 \% \text {, } \\
\text { other exer- } \\
\text { tion } 17 \% \text {, } \\
\text { light tasks } \\
72 \%\end{array}$ & $\begin{array}{l}8-24 \mathrm{~h} \\
\text { median } \\
\text { Range } 1 \mathrm{~h} \text { to } \\
1 \text { week }\end{array}$ & $\begin{array}{l}\text { Vomiting (38), } \\
\text { diplopia (3), } \\
\text { stiff neck } \\
\text { (14), dilated } \\
\text { pupil (1) }\end{array}$ \\
\hline $\begin{array}{l}\text { Harling } \\
1989 \text { [23] } \\
\text { PTCHA }\end{array}$ & 14 & $\begin{array}{l}1.5 \text { to } 2.5 \text { (no } \\
\text { mean given) }\end{array}$ & - & - & 93 & 28 & $\begin{array}{l}\text { Exercise, } \\
\text { weights, sex } \\
21 \%\end{array}$ & $\begin{array}{l}<2 \text { h } 0 \% \\
>2 \text { h } 79 \%\end{array}$ & $\begin{array}{l}\text { Vomiting }(28) \\
(P<0.02), \\
\text { Neck stiffness } \\
(57) \\
\text { Photophobia } \\
(64) \\
\text { Loss of con- } \\
\text { sciousness } \\
(14)\end{array}$ \\
\hline $\begin{array}{l}\text { Harling } \\
1989 \mathrm{SAH}\end{array}$ & 35 & & - & - & - & 43 & $\begin{array}{l}\text { Exercise, } \\
\text { weights, sex } \\
28 \%\end{array}$ & - & $\begin{array}{l}\text { Vomiting (72) } \\
\text { Neck stiffness } \\
(80) \\
\text { Photophobia } \\
(57) \\
\text { Loss of con- } \\
\text { sciousness } \\
(34)\end{array}$ \\
\hline $\begin{array}{l}\text { Markus [24] } \\
\text { PTCHA }\end{array}$ & 18 & 1.7 & 25 & 25 & 50 & 38 & $\begin{array}{l}N(19 \%) \\
\text { Sex 1 } \\
\text { Straining } 1 \\
\text { Lifting 0 } \\
\text { Diving 1 }\end{array}$ & - & $\begin{array}{l}\text { Nausea (88) } \\
\text { Vomiting (44) } \\
\text { Photophobia } \\
(50) \\
\text { Collapse (6) }\end{array}$ \\
\hline $\begin{array}{l}\text { Markus } 1991 \\
\text { SAH }\end{array}$ & 37 & - & 60 & - & - & - & $\begin{array}{l}\text { N (18\%) } \\
\text { Sex 1 } \\
\text { Straining 0 } \\
\text { Lifting 1 } \\
\text { Diving 1 }\end{array}$ & - & $\begin{array}{l}\text { Nausea (60) } \\
\text { Vomiting (68) } \\
\text { Photophobia } \\
\quad(5) \\
\text { Collapse (16) }\end{array}$ \\
\hline $\begin{array}{l}\text { Linn } 1998 \text { [8] } \\
\text { PTCHA }\end{array}$ & 42 & $\begin{array}{l}\text { Data from } \\
\text { first presen- } \\
\text { tation only }\end{array}$ & 14 & - & - & 57 & $\begin{array}{l}\text { Exertion/Val- } \\
\text { salva } 22 \%\end{array}$ & - & $\begin{array}{l}\text { Nausea (76) } \\
\text { Vomiting (43) } \\
\text { Transient loss/ } \\
\text { clouding of } \\
\text { conscious- } \\
\text { ness (16) } \\
\text { Transient focal } \\
\text { symptoms* } \\
\text { (22) } \\
\text { Seizure } 0 \%\end{array}$ \\
\hline $\begin{array}{l}\text { Linn } 1998 \\
\text { SAH }\end{array}$ & 37 & & 19 & - & - & 38 & $\begin{array}{c}\text { Exertion/Val- } \\
\text { salva 50\% }\end{array}$ & - & $\begin{array}{l}\text { Nausea (76) } \\
\text { Vomiting (69) } \\
\text { Transient loss/ } \\
\text { clouding of } \\
\text { conscious- } \\
\text { ness (26) } \\
\text { Transient focal } \\
\text { symptoms* } \\
(33) \\
\text { Seizure (7) }\end{array}$ \\
\hline
\end{tabular}


Table 3 (continued)

\begin{tabular}{|c|c|c|c|c|c|c|c|c|c|}
\hline Publication & $\mathrm{N}$ & $\begin{array}{l}\text { Mean Follow- } \\
\text { up (years) }\end{array}$ & Past TCHA \% & $\begin{array}{l}\text { Recurrent } \\
\text { TCHA \% }\end{array}$ & $\begin{array}{l}\text { Subsequent } \\
\text { primary } \\
\text { HA \% }\end{array}$ & $\begin{array}{l}\text { Prior primary } \\
\text { HA\% }\end{array}$ & $\begin{array}{l}\text { Precipitant to } \\
\text { onset }\end{array}$ & Duration & $\begin{array}{l}\text { Additional } \\
\text { features (\%) }\end{array}$ \\
\hline $\begin{array}{l}\text { Landtblom } \\
2002 \text { [9] } \\
\text { PTCHA }\end{array}$ & 101 & 1 & 29 & 24 & - & $\begin{array}{l}28 \text { Migraine } \\
25 \mathrm{TTH}\end{array}$ & $\begin{array}{l}\text { Exertion/Val- } \\
\text { salva 21\% } \\
\text { Sexual TCHA } \\
9 \%\end{array}$ & - & $\begin{array}{l}\text { Nausea (91) } \\
\text { Neck stiffness } \\
(61) \\
\text { Paresis (13) } \\
\text { Impaired } \\
\text { conscious- } \\
\text { ness (17) } \\
\text { Unconscious- } \\
\text { ness (17) } \\
\text { Photophobia } \\
\text { (9) } \\
\text { Blurred vision } \\
\text { (4) } \\
\text { Scintillation } \\
\text { scotoma (0) } \\
\text { Diplopia (0) }\end{array}$ \\
\hline $\begin{array}{l}\text { Landtblom } \\
2002 \text { SAH }\end{array}$ & 23 & - & 17 & - & - & $\begin{array}{l}22 \text { Migraine } \\
9 \text { TTH }\end{array}$ & $\begin{array}{l}\text { Exertion/Val- } \\
\text { salva } 17 \% \\
\text { Sexual TCHA } \\
9 \%\end{array}$ & - & $\begin{array}{l}\text { Nausea (61) } \\
\text { Neck stiffness } \\
(10) \\
\text { Paresis (3) } \\
\text { Impaired con- } \\
\text { sciousness } \\
\text { (9) Uncon- } \\
\text { sciousness } \\
(4) \\
\text { Photophobia } \\
(4) \\
\text { Blurred vision } \\
(4) \\
\text { Scintillation } \\
\text { scotoma (7) } \\
\text { Diplopia (2) }\end{array}$ \\
\hline
\end{tabular}

PTCHA Primary thunderclap headache, SAH Subarachnoid haemorrhage

*Transient neurological symptoms_-double vision, speech arrest, sensory phenomena or weakness in the face or limbs (unilateral or bilateral), and difficulties with walking

There are also anecdotal reports of treatment responses to acetazolamide [41], naproxen [42], propranolol [43] and lumbar puncture [30,44]. The latter involved removal of $40 \mathrm{ml}$ of cerebrospinal fluid. Constituents were normal.

\section{Primary and secondary cough headache}

Despite the prevalence data of $1 \%$, the published cohorts of cough headache remain small. The assumption is that this is because the disorder tends to be self-limiting and remissions prolonged. The primary cases tend to be more common than secondary cases (Tables 4 and 5). There is a preponderance of published posterior fossa lesions purported to be secondary causes, with ACM I disproportionately represented [45]. The natural history of ACM I in both asymptomatic and symptomatic patients (which includes those with a syrinx) is benign and without progression in the majority [46]. Analysis of ACM I cohorts show that the prevalence of headache is generally in line with population prevalences, although that for cough headache has been reported higher than the $1 \%$ population prevalence [47-49]. Although outcome of headache in those operated upon is reported to be good this is based on a relatively limited follow-up period. In one cohort of 96 patients $75 \%$ had resolution or improvement, the follow-up period was a mean of 3.6 years; the 30 day post-operative complication rate was $27 \%$ and included one death [49]. In another cohort a comparison was made between conservative (68 patients) and operated groups (109 patients). The improvement in cough headache was $40 \%$ and $94.6 \%$, respectively, and for migraine $61.5 \%$ and $92.9 \%$. The mean follow-up period for the conservative group was 4.8 years and that of the operated group only 1.3 years which, does not take into account the natural history of the primary disorder [47]. Moreover, none of the reports can account for the significant impact of surgical placebo [50]. Risks 
of intervention include wound sepsis, meningitis, stroke, CSF fistula and hydrocephalus [46].

Secondary cough headache has also been reported to respond to Indometacin [51, 52]. In the case report of Buzzi, a 54 year-old patient presented with a 10 year history of cough headache as an isolated presentation. She was found to have an abnormal examination and imaging showed a Chiari 1 malformation and a syrinx extending from C7-T7. The episodes of Valsalva-precipitated headache responded to Indomethacin $25 \mathrm{mg}$ bd.

This case highlights the importance of adhering to the Hippocratic principle to 'Do No Harm'. This is particularly pertinent in the cases of patients presenting with valsalva headache, normal neurological examination and a Chiari I. It is clear that not all patients with a Chiari I develop cough headache [45]. The onset of the Valsalva headache occurs in the 5-6th decades while the malformation is considered congenital. Conservative management of paediatric populations, looking at natural history, suggest that the outcome in most patients is benign [53, 54]. There are occasional cases where there is both worsening and improvement; of the latter 3 of 147 patients had spontaneous improvement of the associated syrinx [54]. In Symond's original cohort of cough headache patients, one patient developed symptoms after successful treatment for an acoustic neuroma. Another gave a 10 years history of cough headache with a 4 years history of spontaneous remission; when seen at 10 years she was found to have basilar compression from Paget's disease with abnormal cranial nerve examination and a mild spastic paraparesis [31]. There is a single case report of cough headache, without precipitating thunderclap headache, associated with bilateral acute parietal infarcts and reversible vasoconstriction [55]. Suppression of the headache was achieved with the use of an antitussive, benproperine.

Thus, not only can secondary cough headache respond to medical treatment, but the disorder can also go into spontaneous remission, occur coincidentally and be precipitated by surgical intervention. Accordingly, it is proposed that any surgical intervention should be considered for neurological progression at a point where the risks of surgical intervention are warranted. In isolated cough headache, whether primary or secondary, preventative treatment with Indomethacin can be considered.

\section{Exertional headache}

Population-based prevalence of exertional headache has varied from $1 \%[28,56]$ up to $12.7 \%[57,58]$ with more recent studies citing a female preponderance [56-59].

Table 6 gives the clinical characteristics of exerciserelated headache. The exertional precipitant is usually a sustained strenuous effort which precipitates the headache 


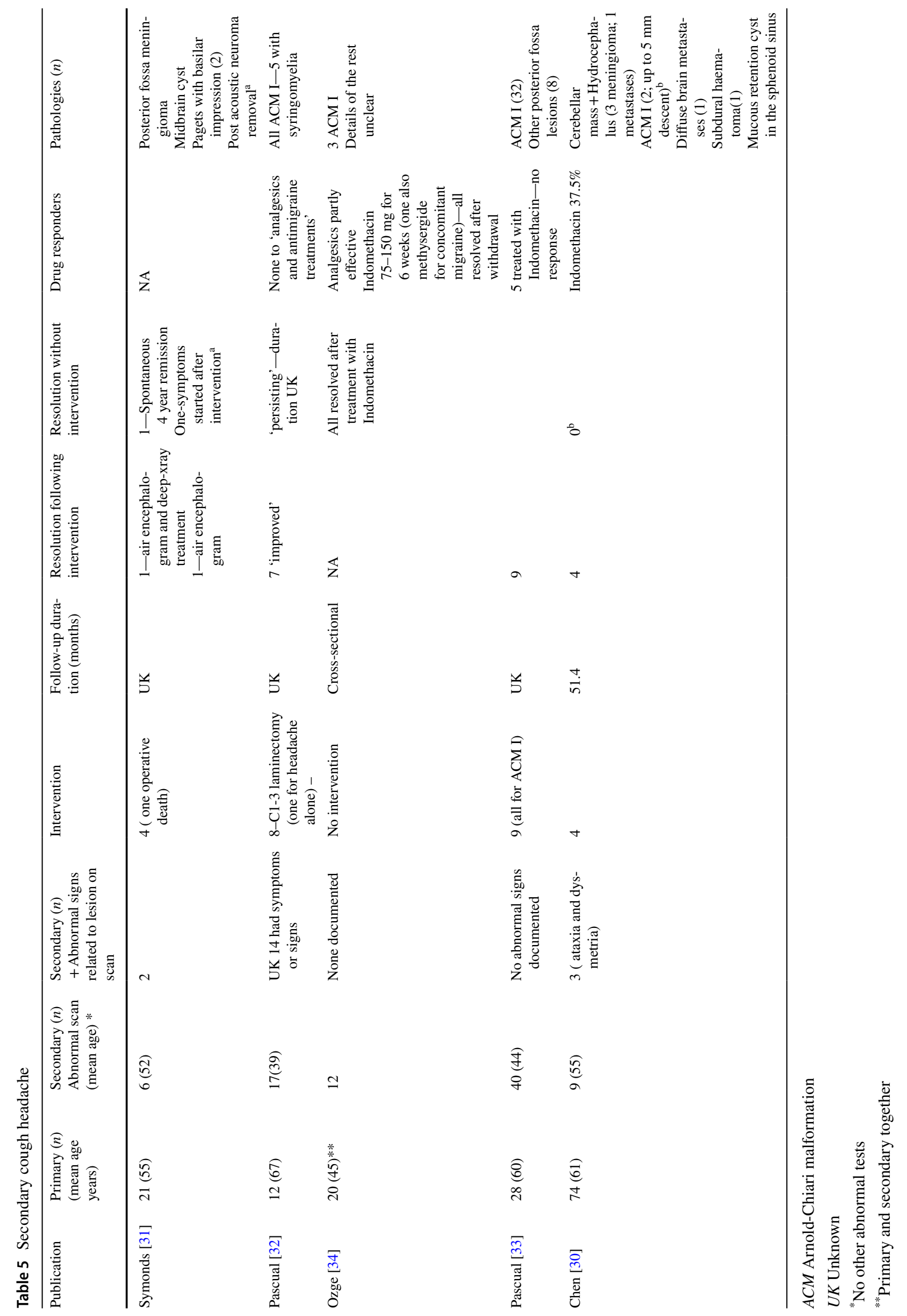


during or after exertion. The attack can last minutes to hours, with the ICHD adopting an upper limit of $48 \mathrm{~h}$ to capture the majority of attacks. The subsequent headache, which is triggered, is usually throbbing and can be accompanied by features usually seen in migraine, albeit at lower frequencies than in migraine. In Hanashiro's small cohort, $17 \%$ and 23\% also experienced valsalva and sexual headache, respectively [56], while in Chen's cohort of over 500 sufferers $47 \%$ had also experienced valsalva related headache. Silbert reports that in his cohort of 45 patients with benign sexual headache $27(60 \%)$ also reported experiencing exertional headache [60]. Bougea reported on three patients with comorbid exertional-, cough-, and sexual headache [61].

There is little information about the natural history of the disorder. That available and that from duration of treatment required, suggests the disorder occurs in self-limiting bouts as brief as a month up to a few years.

\section{Treatment}

Diamond reported on the complete resolution of symptoms with Indomethacin in 13 of his 15 patients within 1-4 weeks; medication was withdrawn after three to 12 months with all but one patient remaining asymptomatic, suggesting natural remission [62]. In Pascual's series of 16 patients 4 seemed to respond to pre-emptive ergotamine, one patient with regular attacks to propranolol and one each to Indomethacin and Flunarizine [32]. Five of nine patients in a later cohort, responded to prophylactic nadolol or propranolol over a period ranging from two to six months [33]

\section{Primary and secondary exertional headache}

The main forms of exertional headache associated with a secondary pathology are those where exertion precipitates a $\mathrm{TCH}$. Management remains as detailed in the section TCH.

\section{Cardiac cephalgia}

Cardiac cephalgia is a rare exertional headache secondary to cardiac ischaemia and responds to treatment of the cardiac ischaemia. The entity is now recognised in the Appendix of the ICHD. A recent 2017 review of the case reports $(n=35)$ [63] found that there was a male preponderance with mean age of onset of 62 years. Half of the cases were precipitated by exertion, sexual activity and emotional fluctuation. The clinical syndrome was of a bilateral or unilateral headache, with or without typically migrainous features but severe in 33 of the patients. Only half presented with characteristics associated with cardiac ischaemia, such as chest pain or tightness, palpitations and dyspnoea. The headache settled with rest and could be eased by anti-anginal treatment such as nitroglycerine spray. This is a particularly useful indicator, given that in headaches of a similar phenotype, namely migraine and tension-type headache, nitroglycerine precipitates the headache [64]. Most cases had an abnormal baseline ECG and elevated cardiac enzymes. Of those who had indicators for cardiac ischemia, three had a normal baseline ECG, one a normal exercise stress test and two normal angiography.

\section{Sexual headache}

The population prevalence of sexual headache is cited as $1-1.6 \%[28,65]$. There is a male preponderance and familial occurrence, one report in mother and daughter [58] and another in four sisters suffering from sexual headache [66]. Primary headache associated with sexual activity is divided into pre- and post-orgasmic forms (Table 2).

Preorgasmic headache is a headache which gradually increases in severity towards orgasm and occurs in about $20 \%$ of cases of sexual headache. Pornography precipitated headache has been reported in a 40 year old man who experienced pre-orgasmic headache within $10 \mathrm{~min}$ of watching pornography, only on the internet. The pain subsided when the patient stopped watching and responded to pre-emptive Indomethacin, taken $15 \mathrm{~min}$ prior to watching [67].

Orgasmic headache is a sudden onset severe pain (thunderclap onset) immediately before or at orgasm and is the mode of presentation in about $80 \%$ of cases.

Sexual headaches are not experienced with every sexual encounter $[32,60,68,69]$. The attacks of headache tend to be short-lived from a few hours, infrequently longer (Table 7). Accompanying symptoms are uncommon, the most frequently cited being nausea. In Frese's cohort of 51 patients, the sexual headache most commonly occurred with sexual activity with the usual partner (94\%), but also during masturbation (35\%), with a new partner (14\%), and only during an extramarital affair in one patient. Twenty patients (40\%) could terminate the headache by stopping sexual activity. Twenty-six patients (51\%) could ease the headache by taking a more passive role during sexual activity. In five patients sexual headache occurred only with specific sexual practices.

Orgasmic aura without headache has been reported in two patients [70]. A 23 year-old woman with a history of migraine, experienced vertigo, oscillopsia and a perception of weakness in the legs at the onset of orgasm, with full recovery by $45 \mathrm{~min}$. Symptoms responded to nifedipine $10 \mathrm{mg}$ twice a day. A 33 year-old man experienced vertigo at orgasm, sometimes accompanying fortification spectra lasting 10-20 min. Pre-emptive diclofenac, an hour before sex, was effective at preventing the symptoms. Independently he could experience 


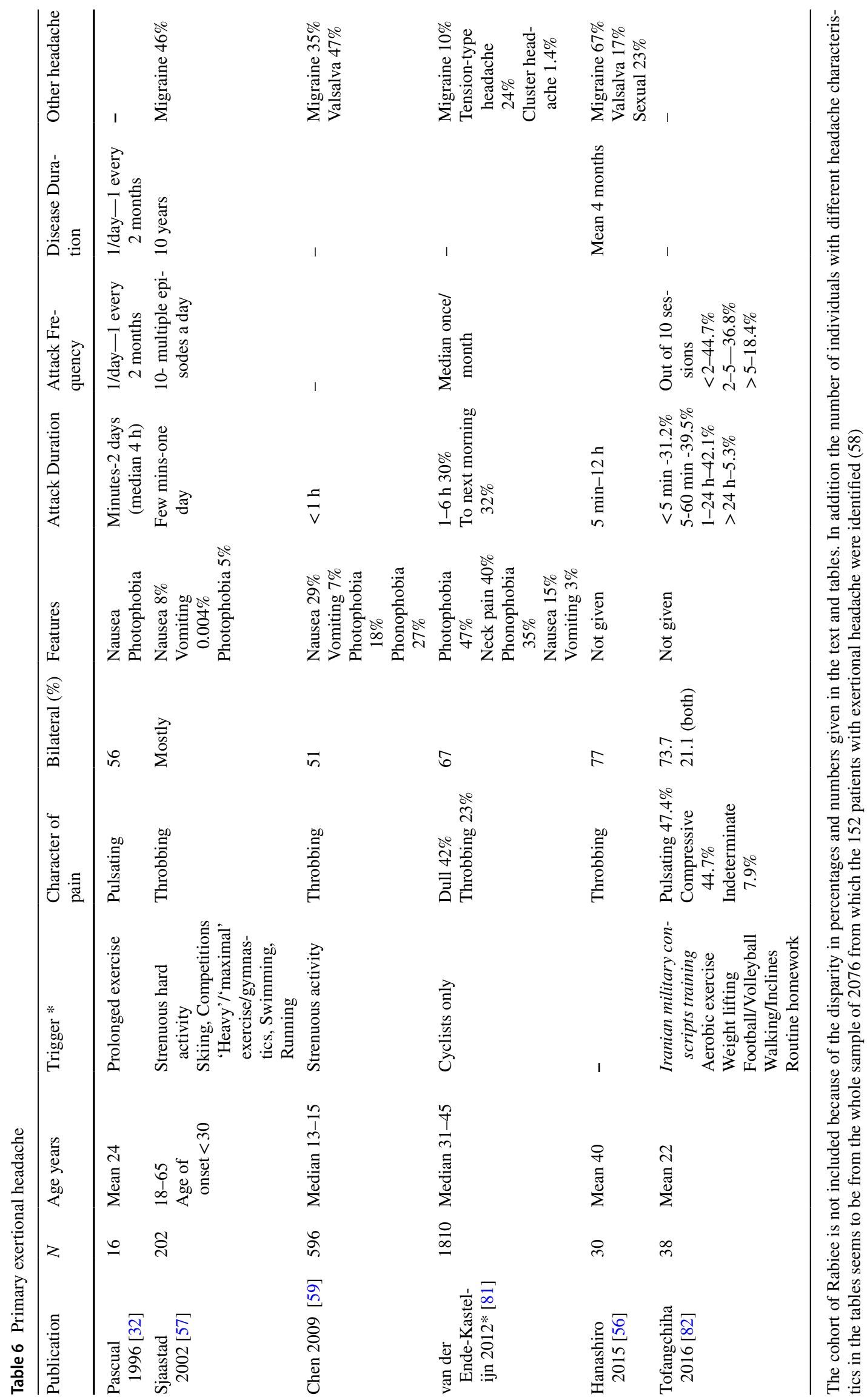


vertigo for $10 \mathrm{~min}$ followed by a migraine headache, lasting up to $6 \mathrm{~h}$.

Particularly given the male preponderance, the prevalence of migraine is higher than the population prevalence, up to $30 \%$. In a cohort of 100 migraine sufferers and 100 controls, none of the latter group had a history of sexual headache while $5 \%$ of those with migraine had also experienced sexual headache [71]. Comorbidity with exertional headache was reported in three of the five cohorts presented in Table 7, while only one cohort reported comorbidity with valsalva-associated headache, in $20 \%$.

As with the other precipitated primary headaches, primary sexual headache seems to occur in bouts with prolonged remissions. The latter is often several years in duration. In Frese's cohort, $82 \%$ had a single bout over a three year follow-up period [72]. Ostergaard's follow-up of 26 patients spanned 6 months to 14 years (median 6 years). Thirteen patients had recurrent bouts of sexual headache interspersed by remissions lasting up to 10 years [73].

\section{Treatment}

The most consistently reported responses in sexual headache are for Indomethacin and betablockers, most commonly cited propranolol, but also metoprolol and nadolol [32, 42, $66,69,74,75]$. Raskin recommended the use of pre-emptive Indomethacin $50 \mathrm{mg}$ after dinner [76], successful in four out of five patients. Prophylactic success with Indomethacin, oral treatment 25 to $100 \mathrm{mg}$ given 30-60 min prior to sexual activity, has corroborated Raskin's experience [77, 78]. Frese reported benefit with triptans for the headache precipitated by sexual activity if attacks usually lasted longer than $2 \mathrm{~h}$. The paper also reported on the preventative benefit of rizatriptan, almotriptan and sumatriptan, $30 \mathrm{~min}$ before sexual intercourse [77].

\section{Primary and secondary sexual headache}

The majority of patients with sexual headache present with thunderclap onset headache and therefore will need to be managed for a possible secondary precipitant. Lundberg reported on 4-12\% of patients, confirmed to have subarachnoid haemorrhage, presenting with sexual thunderclap headache [79]. Headache secondary to spontaneous intracranial hypotension, precipitated by sexual intercourse, is no longer part of the classification for primary sexual headache but is a reported precipitant in spontaneous intracranial hypotension [80].

\section{Summary}

Thunderclap, cough, exertional and sexual headache can occur as both primary and secondary headache disorders, the primary headaches predominating. These disorders can be viewed as modes of onset of a headache, with the subsequent headache most commonly having characteristics of migraine or, tension-type headache. Although thunderclap headache can occur spontaneously, it can also be triggered.

This group of disorders tend to occur in bouts which are self-limiting, in the majority lasting months or a few years. Remissions periods can be prolonged over many years. A regular pattern of bouts and remissions, as seen in cluster headache, is not characteristic. About half are reported to have had a single bout only, during the follow-up periods reported. Patients tend to be more likely to have other comorbid headache disorders than would be expected based on population prevalence. The most consistent treatment responses across the group are seen with Indometacin.

The infrequency with which each disorder is seen, based upon prevalence but also remission periods, makes it more difficult to address the issue of what proportion with the isolated headache syndrome have a primary headache or are secondarily precipitated. More specifically, who should be imaged? It is clear that all patients presenting with a thunderclap headache, whether precipitated or not, will need investigation. The issue is more difficult with cough, exertional and sexual headache because of the risk of identifying an incidental lesion. This is more so because these disorders are self-limiting, thus successful case reports of intervention may simply indicate natural remission. Moreover, the primary and secondary headache phenotypes are identical, therapeutically respond similarly to medical treatment and, intervention for any presumed precipitant does not necessarily result in resolution of the headache. The report of two familes with sexual headache, suggests that, as with the other primary headache disorders, these disorders may also occur in those genetically predisposed. Until there are larger published cohorts to inform whether each phenotype (other than $\mathrm{TCH}$ ) has a higher risk of identifying a brain pathology than a matched asymptomatic population, those with new onset symptoms are likely to be imaged. A pragmatic approach would be to treat any abnormality and the headache independently. It would seem appropriate to reserve intervention based upon neurological progression related to the lesion and not the pain alone. 


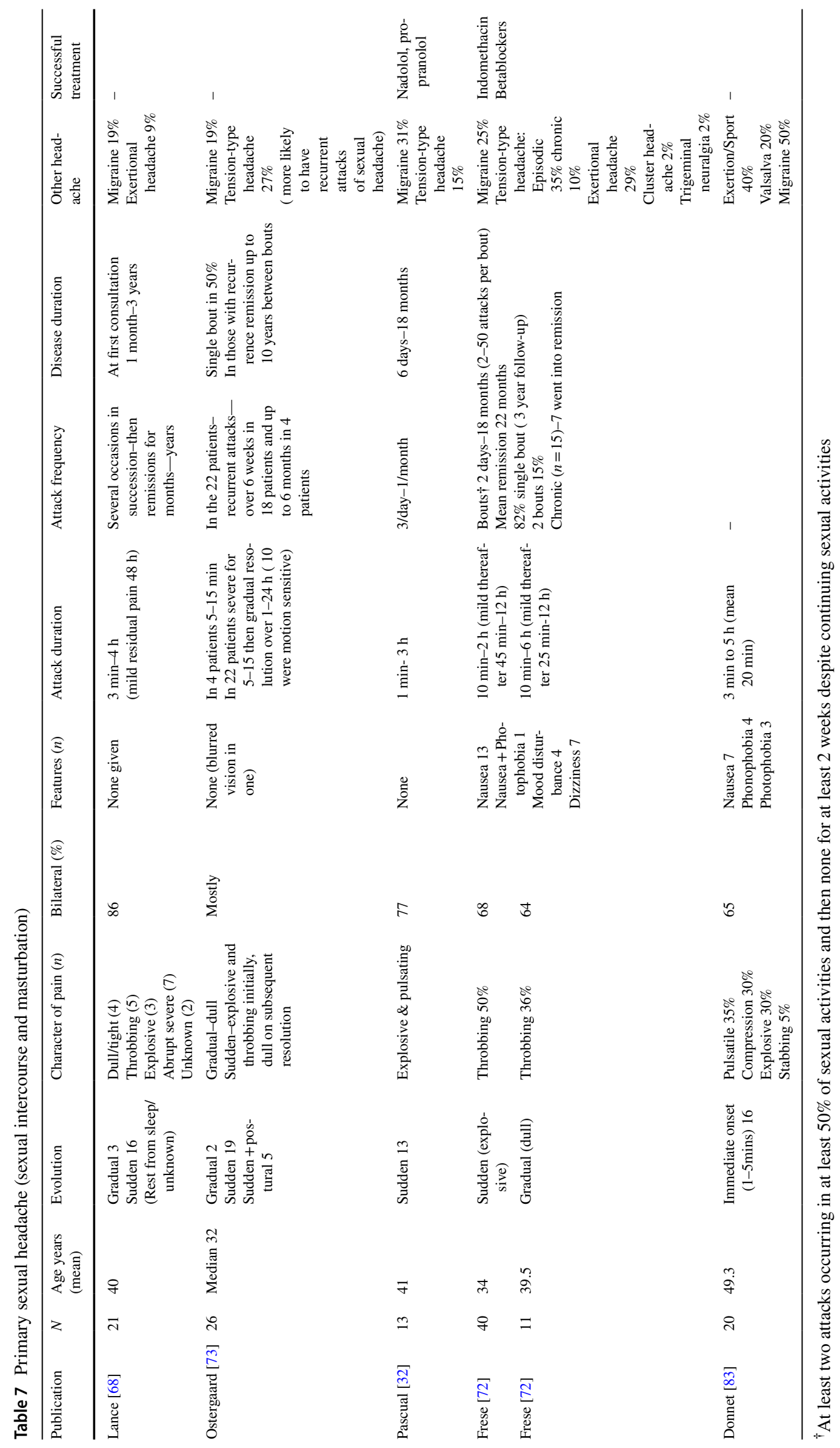




\section{Compliance with ethical standards}

\section{Conflict of interest None.}

Open Access This article is licensed under a Creative Commons Attribution 4.0 International License, which permits use, sharing, adaptation, distribution and reproduction in any medium or format, as long as you give appropriate credit to the original author(s) and the source, provide a link to the Creative Commons licence, and indicate if changes were made. The images or other third party material in this article are included in the article's Creative Commons licence, unless indicated otherwise in a credit line to the material. If material is not included in the article's Creative Commons licence and your intended use is not permitted by statutory regulation or exceeds the permitted use, you will need to obtain permission directly from the copyright holder. To view a copy of this licence, visit http://creativecommons.org/licenses/by/4.0/.

\section{References}

1. Headache Classification Committee of the International Headache Society (IHS) the international classification of headache disorders, 3rd edn. Cephalalgia, 2018. 38(1): 1-211.

2. Anttila V et al (2018) Genetics of migraine. Handb Clin Neurol 148:493-503

3. Gibson KF et al (2019) Genetics of cluster headache. Cephalalgia 39(10):1298-1312

4. Russell MB (2007) Genetics of tension-type headache. J Headache Pain 8(2):71-76

5. Locker TE et al (2006) The utility of clinical features in patients presenting with nontraumatic headache: an investigation of adult patients attending an emergency department. Headache 46(6):954-961

6. Bahra A (2013) Secondary headache. Adv Neurosci Rehabil 3(4)

7. Practice parameter: the utility of neuroimaging in the evaluation of headache in patients with normal neurologic examinations (summary statement). Report of the Quality Standards Subcommittee of the American Academy of Neurology. Neurology, 1994. 44(7):1353-1354

8. Linn FHH et al (1998) Headache characteristics in subarachnoid haemorrhage and benign thunderclap headache. J Neurol Neurosurg Psychiatry 65(5):791-793

9. Landtblom AM et al (2002) Sudden onset headache: a prospective study of features, incidence and causes. Cephalalgia 22(5):354-360

10. Perry JJ et al (2010) High risk clinical characteristics for subarachnoid haemorrhage in patients with acute headache: prospective cohort study. BMJ 341:c5204

11. Nieuwkamp DJ et al (2009) Changes in case fatality of aneurysmal subarachnoid haemorrhage over time, according to age, sex, and region: a meta-analysis. Lancet Neurol 8(7):635-642

12. Lovelock CE, Rinkel GJ, Rothwell PM (2010) Time trends in outcome of subarachnoid hemorrhage: population-based study and systematic review. Neurology 74(19):1494-1501

13. Dubosh NM et al (2016) Sensitivity of early brain computed tomography to exclude aneurysmal subarachnoid hemorrhage: a systematic review and meta-analysis. Stroke 47(3):750-755

14. Backes D et al (2012) Time-dependent test characteristics of head computed tomography in patients suspected of nontraumatic subarachnoid hemorrhage. Stroke 43(8):2115-2119
15. Vermeulen $M$ et al (1989) Xanthochromia after subarachnoid heamorrhage needs no revisitation. J Neurol Neurosurg Psychiatry 52:826-828

16. van der Wee $\mathrm{N}$ et al (1995) Detection of early subarachnoid haemorrhage on early CT: Is lumbar puncture still needed after a negative scan? J Neurol Neurosurg Psychiatry 58:357-359

17. Wood MJ, Dimeski G, Nowitzke AM (2005) CSF spectrophotometry in the diagnosis and exclusion of spontaneous subarachnoid haemorrhage. J Clin Neurosci 12(2):142-146

18. Brown RD, Broderick JP (2014) Unruptured intracranial aneurysms: epidemiology, natural history, management options, and familial screening. Lancet Neurol 13(4):393-404

19. Malhotra A et al (2016) Cost-effectiveness analysis of followup strategies for thunderclap headache patients with negative noncontrast CT. Acad Emerg Med 23(3):243-250

20. Perry JJ et al (2011) Sensitivity of computed tomography performed within six hours of onset of headache for diagnosis of subarachnoid haemorrhage: prospective cohort study. BMJ 343:d4277

21. Blok KM et al (2015) CT within 6 hours of headache onset to rule out subarachnoid hemorrhage in nonacademic hospitals. Neurology 84(19):1927-1932

22. Wijdicks EF, Kerkhoff H, van Gijn J (1988) Long-term followup of 71 patients with thunderclap headache mimicking subarachnoid haemorrhage. Lancet 2(8602):68-70

23. Harling DW et al (1989) Thunderclap headache: is it migraine? Cephalalgia 9(2):87-90

24. Markus HS (1991) A prospective follow up of thunderclap headache mimicking subarachnoid haemorrhage. J Neurol Neurosurg Psychiatry 54:1117-1118

25. Carpenter CR et al (2016) Spontaneous subarachnoid hemorrhage: a systematic review and meta-analysis describing the diagnostic accuracy of history, physical examination, imaging, and lumbar puncture with an exploration of test thresholds. Acad Emerg Med 23(9):963-1003

26. Perry JJ et al (2017) Validation of the Ottawa subarachnoid hemorrhage rule in patients with acute headache. CMAJ 189(45):E1379-E1385

27. Devenney E, Neale H, Forbes RB (2014) A systematic review of causes of sudden and severe headache (thunderclap headache): should lists be evidence based? J Headache Pain 15:49

28. Rasmussen BK, Olesen J (1992) Symptomatic and nonsymptomatic headaches in a general population. Neurology 42:1225-1231

29. Ran Y et al (2017) Laugh-induced headache: clinical features and literature review. Headache 57(10):1498-1506

30. Chen PK, Fuh SJ, Fau J, Wang SJ (2009) Cough headache: a study of 83 consecutive patients. Cephalalgia 29(10): 1079-1085

31. Symonds C (1956) Cough headache. Brain 79:557-568

32. Pascual J et al (1996) Cough, exertional, and sexual headaches: an analysis of 72 benign and symptomatic cases. Neurology 46(6): 1520-1524

33. Pascual J et al (2008) Headaches precipitated by cough, prolonged exercise or sexual activity: a prospective etiological and clinical study. J Headache Pain 9(5):259-266

34. Ozge $\mathrm{C}$ et al (2005) Cough headache: frequency, characteristics and the relationship with the characteristics of cough. Eur J Pain 9(4):383-388

35. Rooke E (1968) Benign exertional headache. Med Clin N Am 52(4):801-808

36. Mateo I, Pascual J (1999) Coexistence of chronic paroxysmal hemicrania and benign cough headache. Headache 39(6):437-438

37. McGeeney BE (2006) Valsalva-induced cluster headache. J Headache Pain 7(6):416-418 
38. Pavao Martins I, Viana P (2017) Cough hemicrania-an overlapping form of headache: case reports. Headache 57(5): 796-800

39. Rozen TD (2019) New daily persistent headache (NDPH) triggered by a single Valsalva event: a case series. Cephalalgia 39(6):785-791

40. Mathew NT (1981) Indomethacin responsive headache syndromes. Headache 21(4):147-150

41. Wang S-J, Fuh J-L, Lu S-R (2000) Benign cough headache is responsive to acetazolamide. Neurolgy 2000(55):149-150

42. Raskin NH (1988) The indomethcin-responsive sydromes. In: Raskin NH (ed) Headache. Churchill Livingstone, New York. p 255-68

43. Calandre L, Hernandez-Lain A, Lopez-Valdes E (1996) Benign Valsalva's maneuver-related headache: an MRI study of six cases. Headache 36:251-253

44. Raskin N (1995) The cough headache syndrome: treatment. Neurology 45(9):1784

45. Martins HA et al (2010) Headache precipitated by Valsalva maneuvers in patients with congenital Chiari I malformation. Arq Neuropsiquiatr 68(3):406-409

46. Langridge B, Phillips E, Choi D (2017) Chiari malformation type 1: a systematic review of natural history and conservative management. World Neurosurg 104:213-219

47. Chavez A et al (2014) Comparison of operative and non-operative outcomes based on surgical selection criteria for patients with Chiari I malformations. J Clin Neurosci 21(12):2201-2206

48. Killeen A et al (2015) Non-operative outcomes in Chiari I malformation patients. J Clin Neurosci 22(1):133-138

49. Hayhurst $\mathrm{C}$ et al (2008) Hindbrain decompression for Chiarisyringomyelia complex: an outcome analysis comparing surgical techniques. Br J Neurosurg 22(1):86-91

50. Wartolowska K et al (2014) Use of placebo controls in the evaluation of surgery: systematic review. BMJ 348:g3253

51. Buzzi MG et al (2003) Chiari-associated exertional, cough, and sneeze headache responsive to medical therapy. Headache 43(4):404-406

52. Ertsey C, Jelencsik I (2000) Cough headache associated with Chiari type-I malformation: responsiveness to indomethacin. Cephalalgia 20(5):518-520

53. Benglis D Jr et al (2011) Outcomes in pediatric patients with Chiari malformation type I followed up without surgery. J Neurosurg Pediatr 7(4):375-379

54. Strahle J et al (2011) Natural history of Chiari malformation type I following decision for conservative treatment. J Neurosurg Pediatr 8(2):214-221

55. Kato $\mathrm{Y}$ et al (2018) Cough headache presenting with reversible cerebral vasoconstriction syndrome. Intern Med 57(10):1459-1461

56. Hanashiro $S$ et al (2015) Prevalence and clinical hallmarks of primary exercise headache in middle-aged Japanese on health check-up. Intern Med 54(20):2577-2581

57. Sjaastad O, LS Bakketeig (2002) Exertional headache. I. Vaga study of headache epidemiology. Cephalalgia 22(10): 784-90.

58. Rabiee B et al (2015) The epidemiology of exertional headache in the general population of Tehran Iran. Headache 55(9):1225-1232

59. Chen SP et al (2009) Exertional headache-a survey of 1963 adolescents. Cephalalgia 29(4):401-407

60. Silbert PL et al (1991) Benign vascular sexual headache and exertional headache. J Neurol Neurosurg Psychiatry 54:417-421
61. Bougea A et al (2015) An uncommon coexistence of primary sexual, cough and exercise headaches: the first three cases from Greece. Hippokratia 19(4):369-371

62. Diamond S (1982) Prolonged benign exertional headache: its clinical characteristics and response to indomethacin. Headache 22(3):96-98

63. Wang $\mathrm{M}$ et al (2017) Cardiac cephalalgia: one case with cortical hypoperfusion in headaches and literature review. J Headache Pain 18(1):24

64. Olesen J, Iversen HK, Thomsen LL (1993) Nitric oxide supersensitivity: a possible molecular mechanism of migraine pain. NeuroReport 4(8):1027-1030

65. Tugba $\mathrm{T}$ et al (2008) Features of stabbing, cough, exertional and sexual headaches in a Turkish population of headache patients. J Clin Neurosci 15(7):774-777

66. Johns DR (1986) Benign sexual headache within a family. Arch Neurol 43(11):1158-1160

67. Chen WH, Chen KY, Yin HL (2018) Pornography headache. Clin Neurol Neurosurg 164:11-13

68. Lance JW (1976) Headaches related to sexual activity. J Neurol Neurosurg Psychiatry 39:1226-1230

69. Paulson GW, Klawans HL (1974) Benign orgasmic cephalgia. Headache 13:181-187

70. Leppan H, Caulfield A (2019) Orgasmic migraine aura: report of two cases. Cephalalgia 39(1):153-156

71. Biehl K, Evers S, Frese A (2007) Comorbidity of migraine and headache associated with sexual activity. Cephalalgia 27(11):1271-1273

72. Frese A et al (2003) Headache associated with sexual activity: demography, clinical features, and comorbidity. Neurology 61(6):796-800

73. Ostergaard JR, Kraft M (1992) Benign coital headache. Cephalalgia 12(6):353-355

74. Frese A et al (2007) Headache associated with sexual activity: prognosis and treatment options. Cephalalgia 27(11):1265-1270

75. Porter M, Jankovic J (1981) Benign coital cephalalgia. Differential diagnosis and treatment. Arch Neurol 38(11):710-712

76. Hu XH et al (2002) Treatment of migraine with rizatriptan: when to take the medication. Headache 42(1):16-20

77. Frese A et al (2006) Triptans in orgasmic headache. Cephalalgia 26(12):1458-1461

78. Anand KS, Dhikav V (2009) Primary headache associated with sexual activity. Singapore Med J 50(5):e176-e177

79. Lundberg PO, Osterman PO (1974) The benign and malignant form of orgasmic cephalgia. Headache 14(3)

80. Schievink WI, Louy C (2007) Precipitating factors of spontaneous spinal CSF leaks and intracranial hypotension. Neurology 69(7):700-702

81. van der Ende-Kastelijn K, Oerlemans W, Goedegebuure S (2012) An online survey of exercise-related headaches among cyclists. Headache 52(10):1566-1573

82. Tofangchiha S, Rabiee B, Mehrabi F (2016) A study of exertional headache's prevalence and characteristics among conscripts. Asian J Sports Med 7(3):e30720

83. Donnet A et al (2013) Primary cough headache, primary exertional headache, and primary headache associated with sexual activity: a clinical and radiological study. Neuroradiology 55(3):297-305 